\title{
A Creative Economy Development Strategy: The Case of Trenggalek Creative Network for Trenggalek Regency, Indonesia
}

\author{
Yuli AGUSTINA ${ }^{1}$, Agung WINARNO ${ }^{2}$, Heri PRATIKTO ${ }^{3}$, Bagus Shandy NARMADITYA ${ }^{4}$, Filianti FILIANTI ${ }^{5}$
}

Received: September 10, 2020 Revised: November 02, 2020 Accepted: November 16, 2020

\begin{abstract}
The purpose of this research aims to develop the creative economy sector of rural communities in Trenggalek Regency, East Java, Indonesia by mapping the creative economy sub-sectors in Trenggalek Regency. The creative economy industry has been shown to have a positive effect on GDP in many developing countries and developed countries. In urban areas, the creative economy is often associated with the development of advanced technology, such that it is unlikely to evolve in rural communities. However, the rural environmental landscape, which not only has a wealth of creative human capital but also a cultural heritage, also encourages the growth of the creative economy sector in rural areas. This qualitative research was conducted for 60 working days through in-depth interviews, focus group discussions, observation and literature review. More precisely, first, it identified the potential of the creative economy both sectorally and regionally. Second, it identified the leading creative economy subsectors and compiled a creative economic development road map. After defining and mapping the potential of the creative economy, four of the sixteen sub-sectors of the creative economy were identified to be developed through a strategic plan for the growth of the creative economy using urban branding, innovative industrial centers and renewable resources.
\end{abstract}

Keywords: Creative Economy, Economic Development, Rural Communities, Trenggalek District

JEL Classification Code: O21, O34, O35, R11

\section{Introduction}

It has been shown that the creative economy sector can have a significant effect on the country's economy, and many countries make it the cornerstone of the national

${ }^{1}$ First Author and Corresponding Author. Management Department, Faculty of Economics and Business, Universitas Negeri Malang, Indonesia [Postal Address: Jalan Semarang No. 5, Malang, East Java 65145, Indonesia] Email: yuli.agustina.fe@um.ac.id

${ }^{2}$ Management Department, Faculty of Economics and Business, Universitas Negeri Malang, Indonesia.

Email: agung.winarno.fe@um.ac.id

${ }^{3}$ Management Department, Faculty of Economics and Business, Universitas Negeri Malang, Indonesia.

Email: heri.pratikto.fe@um.ac.id

${ }^{4}$ Economic Development Department, Faculty of Economics and Business, Universitas Negeri Malang, Indonesia.

Email: bagus.shandy.fe@um.ac.id

${ }^{5}$ Management Department, Faculty of Economics and Business,

Universitas Negeri Malang, Indonesia. Email: filianti40@gmail.com

(C) Copyright: The Author(s)

This is an Open Access article distributed under the terms of the Creative Commons Attribution Non-Commercial License (https://creativecommons.org/licenses/by-nc/4.0/) which permits unrestricted non-commercial use, distribution, and reproduction in any medium, provided the original work is properly cited. economy; for example, what happened in England, Brazil, South Korea, Ireland, Scotland and Canada (Bell \& Jayne, 2010; Coles, 2016; de Figueiredo et al., 2019; Kim, 2017; Munro, 2017; Townsend et al., 2017). Each country has a focal point in working on the creative economy sub-sector in order to maximize the potential of its human resources in order to drive the strength of the national economy. In Indonesia, the creative economy has been seen since 2009 and is increasingly providing promising evidence. The latest report by Bekraf (2019) states that the creative economy sector is able to contribute 1.102 trillion Rupiah to Indonesia's GDP and has absorbed as many as seventeen million workers. Indonesia has also risen to unicorns eager to spread overseas through this sector, for instance, Gojek, Traveloka, Tokopedia and BukaLapak.

UNCTAD (2018) believes that the creative economy, on the other hand, has the opportunity to develop jobs, stimulate exports and improve the economy, as well as foster social inclusion, cultural prosperity and human creativity. Interestingly, by focusing on limitless global capital, specifically human creativity, the creative economy offers a specific strategy for economic growth (Coles, 2016). The Indonesian government, through Bekraf, describes the 
creative economy as an expression of the additional value of human creativity and establishes intellectual property rights based on cultural heritage, science and technology (Bekraf, 2019). Although the creative economy tends to lead to the use of technology and is more likely to be developed in urban areas, in fact it has also been developed in rural areas. White (2010) emphasizes that the creative economy sector cannot be developed only in the urban areas that are close to technology, it can also be developed in rural areas and has proven successful in several areas by maximizing the cultural potential that is owned (de Figueiredo et al., 2019; Fahmi et al., 2016). Even the development of creative economy in rural areas is considered to have more potential than the urban areas, rural areas offer quality in terms of tranquility, landscapes, close community life and the idea of a more relaxed lifestyle that cannot be found in urban environments (Townsend et al., 2017).

The growth of the creative economy sector in rural areas has the potential to create high-quality and sustainable jobs opportunities and contribute to the rural diversification (White, 2010), one of which is through the richness of arts and culture that is owned and becomes an important source of pride for rural communities (Anderson et al., 2016). The United Kingdom as one of the originating countries of the creative economy has also developed it in a rural environment. The creative industry in rural England offers its local economic wealth and is able to contribute to tourism, thereby increasing the enthusiasm of rural communities as a destination that can be visited (Townsend et al., 2017). Baeker and Taylor (2008) in his research opens a global discussion about creative economy in rural environments and its potential for economic reform and development of rural communities. This discussion is important to be undertaken in order to better understand how rural communities are exposed to increasingly lucrative creative economic opportunities.

This study aims to identify and develop the creative economy potential in Trenggalek Regency, East Java Province of Indonesia as part of the synergy between mapping existing regional potential and development of centered community's creative economy. In more detail, it is expected to: firstly, mapping the potential of the regions based on the creative economy. Secondly, formulating strategies in order to develop the creative economy. Thirdly, manifesting Trenggalek Regency as a creative region through a city branding called Trenggalek Creative Center (TCN). Coles (2016) states that as an economic policy framework, the creative economy is framed as a forward approach in addressing the challenges of the post-industrial landscape and fundamentally changing the nature of work and working relationships. Furthermore, Strzelecka (2016) states that to include the creative sector in regional development policies, creative support from local governments is needed.

\section{Literature Review}

\subsection{Creative Economy in Indonesia}

Among developed countries such as the United Kingdom, Canada and the United States, the creative economy is the main driver of innovation, employment and economic growth for the country (Florida \& Adler, 2019). Besides being able to overcome economic problems, the implementation of creative industry policies within the scope of the creative economy in big cities has also become the main strategy in overcoming social problems through industrial focal points that attract, nurture and retain creative practitioners in urban areas (Bell \& Jayne, 2010). The creative economy sector provides a new vital spark to carry out economic development in the midst of increasingly distressing global environmental conditions, in other word climate change. Moreover, Faradiba and Zet (2020) in their research results reveal that in formulating rural development policies, the government must pay attention to the issue of global warming. Through the provision of resources that will never run out of time, in other word human creativity (Coles, 2016; Guilherme, 2017), the creative economy is predicted to be the essential aspect of the national economy of many countries, one of which is Indonesia.

Creativity is a driving force and a major feature in the circulation of the creative economy (Fazlagić \& Skikiewicz, 2019; Florida \& Adler, 2019). Creativity is the property within each individual in varying degrees, irrespective of social status, age, ethnicity, gender and the sexual preference (Florida \& Adler, 2019). Howkins (2001) in his book defines creative economy as an economic activity in a society that spends much of its time generating ideas, not just doing routine and repetitive things, so generating ideas for this society is something that needs to be done to make progress. In the regional context, Indonesia, through Bekraf, describes the creative economy in regional terms as a manifestation of the added value of human imagination and establishes intellectual property rights based on cultural heritage, science and technology (Bekraf, 2019). Furthermore, in Indonesia, the creative economy is an intensification of information and creativity that relies on ideas and knowledge based on human creativity as the main factor in economic productivity activities (Sopanah et al., 2018).

The development of the creative economy sector from year to year has become so encouraging that it becomes news as to which policymakers recognized the creative industry's role in accelerating economic growth (Fleischmann et al., 2017). The creative economy sector is aimed, in line with time and technology, not only in urban areas and developed countries, but also in developing countries (Guilherme, 2017), 
including rural areas. In Indonesia, the development of creative economy systematically started with Presidential Instruction (Perpres) No. 6 of 2009 concerning creative economy development, which succeeded in formulating the Master Plan for Indonesian Creative Economy Development for 2009-2025 in (Perpres No 72 Tahun, 2015) by the Ministry of Trade of the Republic of Indonesia. According to the perspective of the Indonesian government, the creative economy sector needs to be developed because it is a powerful way to increase the competitiveness of national products in facing the global market because in the context of globalization, competitiveness is the main key to success and survival. This rivalry exists not only in the context of large quantities of goods, but also in terms of quality (Tsai et al., 2009).

In addition, seeing the large potential of the creative economy sector for the contribution of the country's GDP, the Indonesian government seriously continues to develop this sector, one of ways is through the Bekraf's flagship program, namely the Independent Assessment of Indonesian Creative Cities/Regencies (PMK3I) where the Indonesian government maps ecosystems, potentials, best practices, and problems with the development of the district/city creative economy system. The government continues to encourage the development of the creative economy sector in every city and district in Indonesia. Unfortunately, not all districts and cities have carried out mapping of the ecosystem and its potential in the area. One of them is in Trenggalek Regency. Until 2019, Trenggalek Regency was not included in the Creative City/ Regency list. Trenggalek Regency currently has several forms of creative industries, but it is important to take effective and focused action in such a way that the creative economy can ultimately promote regional economic development and can prove beneficial for the community. The government of the Trenggalek Regency seeks to manifest itself as a Creative Regency.

\subsection{The Sub-Sector Scope of The Creative Economy in Indonesia}

The creative economy is not just a collection of subsectors wrapped in new ideas, but a symbol of a new economic cycle that has emerged in response to global problems so far (Reis, 2008). This will promote the introduction of new business models, and how government agencies separate the sub-sectors of the creative economy, connecting cultural, social, technical and other aspects. The creative industry, which has different sub-sectors (specializations), generates a kind of convergence of factors that can influence regional economic growth, and this is what Poland has experienced over the last few decades (Strzelecka, 2016). According to UNCTAD (2018), in its report, has grouped the creative economy sub-sectors into eight sub-sectors such as: arts crafts, architecture, design, fashion, media, performing arts, tourism, and several other related subsectors. However, it must be admitted that the fact that implementation in each country that develops the creative economy sector has more varied sub-sectors (Fazlagić \& Skikiewicz, 2019), where this is more adjusted to the potential ownership of each country. Although there are different sub-sectors, basically all activities in this subsector are trading human creative assets in the form of intellectual property (Andres \& Round, 2015).

When considered as a whole, the creative economy sector is very complex in scope, including, for example, businesses engaged in music, film, advertising, handicrafts and video games (Townsend et al., 2017). In the United Kingdom, as one of the originating countries and centers of the creative economy, it divides its sub-sectors into eleven sub-sectors, including advertising, architecture, arts and culture, crafts, createch (creative technology), design, fashion, games, music, publishing and TV \& film. Not much different from the UK but more broadly, the creative economy sub-sector in Ireland includes advertising, architecture, arts/antiques trade, crafts, design, fashion designing, digital media, publishing, Internet \& software, music, visual \& performing arts, radio $\&$ TV, video, and film \& photography (Strzelecka, 2016).

In Indonesia, the majority of the classification of the creative economy sub-sector meets the UK model in effect (Fahmi et al., 2016). The expansion of the sub-sectors was carried out by BEKRAF in order to adapt to the conditions of the creative economy in Indonesia, which produces more creative economy products based on culture, especially in rural areas. Based on Presidential Decree No.6 of 2015 and Presidential Decree Number 72 of 2015 concerning the Creative Economy Agency, there are sixteen creative economy sub-sectors in Indonesia that must be developed as shown in Table 1.

Each city and district in Indonesia has a different potential for developing the creative economy sector. This means that Bekraf gives versatility to each region on the prospect of which sectors can be established in those regions (cities/ regencies) by looking at their potential.

\subsection{General Conditions of the 16 Sub-Sectors of The Creative Economy In Indonesia}

The creative industry is a part or subsystem of the creative economy, which consists of the core creative industry, forward and backward linkage creative industry (Fathurahman \& Huseini, 2018; Hsiao et al., 2010). Core creative industry is a creative industry where the creation of added value is mainly the use of the creativity of creative people (Florida \& Adler, 2019) which requires output from other industries as input during the added value creation process. 
Table 1: Scope/Categories of Sixteen Creative Industry Sectors

\begin{tabular}{|c|c|c|}
\hline No & Subsector & Scope/Categories \\
\hline 1 & $\begin{array}{l}\text { Architecture } \\
\text { Architectural }\end{array}$ & $\begin{array}{l}\text { consulting services, property/architectural works that have artistic and cultural values that } \\
\text { can be an attraction/landmark of an area (city/district) }\end{array}$ \\
\hline 2 & Interior Design & Design consulting services, design education services \\
\hline 3 & $\begin{array}{l}\text { Visual communication } \\
\text { design }\end{array}$ & Consulting services, design education services \\
\hline 4 & Product design & Consulting services, design education services \\
\hline 5 & $\begin{array}{l}\text { Films, animation, and } \\
\text { video }\end{array}$ & $\begin{array}{l}\text { Recording media reproduction business; production studios and post-production of film, } \\
\text { video and television programs; film, video and television program distribution businesses; } \\
\text { film screening services; merchandise business }\end{array}$ \\
\hline 6 & Photography & services, photography education services \\
\hline 7 & Crafts & $\begin{array}{l}\text { Textile, leather, wood, wicker, paper, glass, metal-based handicraft business; furniture } \\
\text { business, jewelery and valuables }\end{array}$ \\
\hline 8 & Culinary & Restaurant/cafe, food and beverage business \\
\hline 9 & Music Musical & $\begin{array}{l}\text { instrument manufacturing business, music education services, musical performances, } \\
\text { music recording studio, music publishing }\end{array}$ \\
\hline 10 & Fashion & Clothing manufacturing business, leather goods, mats feet \\
\hline 11 & $\begin{array}{l}\text { Game and Application } \\
\text { Developer }\end{array}$ & $\begin{array}{l}\text { Merchandise, publisher, game and application development businesses as well as kid's } \\
\text { toys design and development }\end{array}$ \\
\hline 12 & Publishing & Printing business, book/magazine publishing business \\
\hline 13 & Advertising & services \\
\hline 14 & Television and Radio & broadcasting business and television \\
\hline 15 & Performing arts & $\begin{array}{l}\text { buildings, dance performance activities, theater performance activities, performing arts } \\
\text { education services }\end{array}$ \\
\hline 16 & Fine arts & Exhibition buildings/art exhibitions, fine arts education services \\
\hline
\end{tabular}

In this position, the backward linkage creative industry becomes the input for the core creative industry. The output from the core creative industry can also be an input for other industries, which is known as the forward linkage creative industry. It can be concluded that the sixteen groups of creative industries in Indonesia intersect with each other by looking at the connections between industrial groups as the core creative industries, backward and forward relation industries, even though each industrial group has distinct industrial features.

In general, the sixteen creative economy sub-sectors in Indonesia are able to contribute to Indonesia's GDP. In 2017, there were three creative economy sub-sectors that contributed the biggest contribution to the creative economy, namely culinary at $41.69 \%$, crafts at $15.70 \%$, and fashion at $18.15 \%$. The following year, namely 2018 , the conditions changed where there were four creative economy subsectors that had the potential to become a new economic force, namely film, music, art, and games/animation (Bekraf, 2019). Table 2 below is an overview of the entire creative economy sub-sector in Indonesia.

\section{Research Methods and Materials}

This study was qualitative research with the implementation of the research phases, including the identification and mapping of the creative economy potential in Trenggalek Regency, East Java, Indonesia, both by sector, i.e. by sub-sectoral and regional creative economy, i.e. by district and Villages/Sub-district by defining the leading creative economy sub-sectors of Trenggalek Regency and formulating strategic measures for the growth of the creative economy of Trenggalek Regency.

This research has been undertaken for 60 working days. The objectives of this research were indeed: 1) the identification of the leading creative economy sector and the potential to be established as the focal point for the development of the creative economy in Trenggalek Regency from 16 sub-sectors; 2) the formulation of operational standards and guidelines for the development of policies for the Trenggalek Regency Government in the development of the creative economy; and 3) the formulation of guidelines for the development of the creative economy. 
Table 2: The Summary Condition of 16 Creative Economy Sub-sector in Indonesia

\begin{tabular}{|l|c|c|c|l|}
\hline Subsector & $\begin{array}{c}\text { Growth rate } \\
\text { of GDP }\end{array}$ & $\begin{array}{c}\text { Value of GDP } \\
\text { Produced }\end{array}$ & $\begin{array}{c}\text { Number of } \\
\text { Businesses }\end{array}$ & \multicolumn{1}{|c|}{ Number of Workers } \\
\hline Architect & $6.05 \%$ & 21,567 B IDR & 5740 & $53,844,92 \%$ male and $7.61 \%$ female \\
\hline Interior design & $5,92 \%$ & $1,483.7$ B IDR & 798 & $23,967,77.7 \%$ male and $22.3 \%$ female \\
\hline $\begin{array}{l}\text { Visual Communication } \\
\text { Design }\end{array}$ & $8.98 \%$ & 579.3 B IDR & 616 & $92 \%$ male and $7.95 \%$ female \\
\hline Product design & - & 2,281 B IDR & 3,367 & $53.96 \%$ male and $46.04 \%$ female \\
\hline Film, animation and video & $10.09 \%$ & - & 2418 & 39,546 \\
\hline Photography & $6.89 \%$ & - & 40,436 & $69,826,91.77 \%$ male and $8.23 \%$ women \\
\hline Craft & $15.40 \%$ & 142 T IDR & $1,194,509$ & $\begin{array}{l}3.72 \text { million, 54.03\% men and } 45.97 \% \\
\text { women }\end{array}$ \\
\hline Culinary & $41.40 \%$ & 381,985 B IDR & $5,550,960$ & $7,983,259$, \\
\hline Music & $7.59 \%$ & 4,426 B IDR & 34,242 & $\begin{array}{l}56,891,82.85 \% \text { male and } 17.15 \% \\
\text { female }\end{array}$ \\
\hline Fashion & $18.01 \%$ & 166.1 T IDR & $1,230,988$ & $\begin{array}{l}4,130,000,45.75 \% \text { male and } 54.25 \% \\
\text { female }\end{array}$ \\
\hline $\begin{array}{l}\text { Games and application } \\
\text { developer }\end{array}$ & $8.06 \%$ & $17,142.8$ B IDR & 12,441 & 41,065 \\
\hline Publishing & $6.32 \%$ & $58,313.2$ B IDR & 83,496 & $\begin{array}{l}464,579,88.47 \% \text { male i and } 11.53 \% \\
\text { female }\end{array}$ \\
\hline Advertising & $7.07 \%$ & 7.57 T IDR & 3,055 & and $17,97 \%$ female \\
\hline TV \& Radio & $8.27 \%$ & - & 12,441 & $\begin{array}{l}40,990,82.03 \% \text { male71,294, } 41.32 \% \\
\text { male -male and } 58.68 \% \text { female }\end{array}$ \\
\hline Performing arts & $9.54 \%$ & - & 19,772 & $\begin{array}{l}170,994,76.24 \% \text { male and } 23.76 \% \\
\text { female }\end{array}$ \\
\hline Fine arts & - & - & 17,044 & $76.05 \%$ male and $23.95 \%$ female \\
\hline
\end{tabular}

The university is a major center of growth in the creative economy through improving education for its students (Moreton, 2018; Oakley \& Ward, 2018; Wilson, 2010). In some circumstances, this definition is broadened as universities play a role in helping the government grow the creative economy market. The planning of the Trenggalek Regency Creative Economy Growth Roadmap for 2019-2023 was also carried out independently in partnership with other government agencies, namely the State University of Malang, which served as consultants in the implementation of creative economic development. Metze (2009) uses a research approach by using deliberation or more generally referred to as FGD (Focus Group Discussion) to explore the restoration of the artistic industry in the Netherlands. The implementation of the FGD with Trenggalek Regency government officials was also carried out in this study.

\section{Results and Discussion}

\subsection{The Potential of Trenggalek Regency}

Each city or district and often a country that is developing the creative economy sector has its own potential to grow its creative economy sector (Schlesinger, 2017). For example, in Ontario Canada, the most favored sector is the film industry (Coles, 2016) and in rural England it is the tourism village (Townsend et al., 2017). In Indonesia, President Joko Widodo pointed out that he did not have high expectations for the technology sector, but for the arts and crafts sector, which proved to have enormous economic and social benefits (BEKRAF, 2019). Trenggalek Regency, as a field that researchers have developed in the creative economy sector, also has its own potential. 
The creation of a creative industrial center requires a strategic geographical location (Fleischmann et al., 2017) such as the geographical wealth of a region. Trenggalek Regency is one of the rural areas of the eastern province of Java, which is located in the southern part of the province and has mountain and karst-shaped areas with many beaches and open seas (Atana \& Purwohandoyo, 2016). The majority of its territory is mountainous and the economic activity is dominated by the agricultural, trading and manufacturing sectors. In the processing industry, there were 23,963 companies with an investment value of Rp. 85,865 billion and a production value of Rp. 1,617,209 M (Trenggalek District, 2014). The number of beaches and mountains also opens up opportunities for opening tourist attractions in the Trenggalek Regency which can have a significant economic impact, especially in the creative economy sector. In addition, there are also many potentials found in the Trenggalek Regency area as shown in Table 3.

Table 3: The Leading Sectors of Trenggalek Regency

\begin{tabular}{|c|c|c|c|}
\hline No & Sector & Type of & Location \\
\hline \multirow[t]{4}{*}{1} & \multirow[t]{4}{*}{ Farming } & Cassava as many as 350,463 tons of & District of Pule, Bendungan and Panggul. \\
\hline & & Rice 149,220 tons & $\begin{array}{l}\text { District of Panggul, Karangan, Durenan and } \\
\text { Pogalan }\end{array}$ \\
\hline & & $\begin{array}{l}\text { 25,594 Kw Durian Horticultural Lands with } \\
\text { 429,085 Trees in }\end{array}$ & $\begin{array}{l}\text { District of Watulimo, Munjungan, Kampak and } \\
\text { Panggul }\end{array}$ \\
\hline & & $2,542 \mathrm{Kw}$ of Manggis, with 161,106 Trees of 759 & District of Watulimo \\
\hline \multirow[t]{3}{*}{2} & \multirow[t]{3}{*}{ Plantation } & Cocoa, 25 Ton & District of Pule, Karangan, and Kampak \\
\hline & & Coconut As many as 10609.75 Ton & District of Karangan, Panggul, Tugu and Watulimo \\
\hline & & Cloves much as 536.75 Ton & District of Pule, Watulimo, and Panggul \\
\hline \multirow[t]{3}{*}{3} & \multirow[t]{3}{*}{ Farm } & $\begin{array}{l}\text { Dairy With } 5405 \text { population and Milk Production } \\
\text { of } 8.03 \text { million liters }\end{array}$ & District of Bendungan \\
\hline & & $\begin{array}{l}\text { Beef with a population of } 42560 \text { and Meat } \\
\text { production as many as } 7992.10 \text { Ton Meat } \\
\text { Production }\end{array}$ & District of Tugu dan Pogalan \\
\hline & & $\begin{array}{l}\text { Goat with total population of } 226470 \text { and a tail as } \\
\text { much as } 891.9 \text { Ton Meat Production }\end{array}$ & District of Dongko and Munjungan \\
\hline \multirow[t]{2}{*}{4} & \multirow[t]{2}{*}{ Fishing } & $\begin{array}{l}\text { Fishing Marine product as many as } 41,085,702 \\
\text { Kilograms. The potential of active fishermen is } \\
9,656 \text { people }\end{array}$ & District of Watulimo, Munjungan, and Panggul \\
\hline & & $\begin{array}{l}\text { Catfish farming is } 2,053,280 \text { Kilograms and carp } \\
\text { fish as many as } 368,910 \text { Kilograms; the rest are } \\
\text { tilapia and nile tilapia, }\end{array}$ & District of Watulimo, Munjungan and Durenan \\
\hline \multirow[t]{5}{*}{5} & \multirow[t]{5}{*}{ Mining } & $\begin{array}{l}\text { Marble mine has a potential of } 708.548 \text { million } \\
\text { tons }\end{array}$ & District of Panggul, Mangaan \\
\hline & & $\begin{array}{l}\text { Mangan mine has a potential of } 1.0301 \text { million } \\
\text { tons }\end{array}$ & District of Gandusari, Pogalan, and Watulimo \\
\hline & & Kaolin mine has 1.35 million tons & $\begin{array}{l}\text { District of Karangan, Bendungan and District of } \\
\text { Dongko }\end{array}$ \\
\hline & & Tempe Chips Industry & $\begin{array}{l}\text { District of Tamanan and Bendorejo District of } \\
\text { Pogalan }\end{array}$ \\
\hline & & $\begin{array}{l}\text { Roof tiles industry with } 1,550 \text { tile production } \\
\text { houses }\end{array}$ & $\begin{array}{l}\text { Sukorejo Village, Wonorejo Village, Village } \\
\text { Wonoanti District of Gandusari and Kamulan } \\
\text { Village District of Durenan }\end{array}$ \\
\hline
\end{tabular}




\subsection{Creative Economy Development Strategy of Trenggalek Regency}

It is followed by the music industry as many as 29 market players, the design industry as many as 26 major companies with traditionally written batik design as their predominant fashion, the performing arts industry with nineteen industry players, the photography industry with ten industry players, the TV and radio industry with as many as seven industry players, and the publishing sector with five industry players, the architecture and film sector, the animation and video industry with three industry players each, the fine arts sector with two industry players, and the last one is the application and gaming sector with one major company.

On the basis of this data, it can be seen that the existence of Trenggalek Regency as a rural environment that is driven to grow the creative economy also has a number of creative industries that tend to exist in urban areas such as games and entertainment, television and radio, and photography, although the numbers are still very small. White (2010) shows that rural areas in the western part of Ireland are also expanding the creative economy sector and have contributed $3 \%$ of existing jobs. The creative economy sub-sector is dominated by local micro-scale businesses. The research results by Munro (2017) also indicate that the development of the creative economy sector in rural areas is more established from small, micro-scale industries rather than larger sectors. If it is further observed, this also occurs in Trenggalek Regency which has many micro-scale industries and many of these are developing in the culinary and crafts sub-sectors.

Based on the above results, the action plan can be based on the industrial sector that has the most participants, namely the culinary sector. So that the action plans that can be drawn up are, for example, culinary production, the development of national tempe products, the cultural festival "sego gegog," "rame nduren" and the culinary festival of Trenggalek Regency. The next action plan relates to the craft market, where many action plans can be implemented, such as the National Program Program, Bamboo Creativity, Trenggalek Creart (Creative Art Trenggalek) and the Woodever Festival. The next action plan relates to the music industry market, where many action plans can be enforced, such as the Islamic Music Festival and the Keroncong Parade. Action plans related to the fashion industry, such as the Batik Festival, the Trenggalek Fashion Festival. Action plans for the performing arts market, such as Contemporary Wayang Performance, Dance and Performance Arts. Action plans related to the photography industry are for instance the Beautiful Trenggalek Exhibition (Photography) and the Street Photo Exhibition in Trenggalek. Bell \& Jayne (2010) believes that the implementation of local festivals is critical for the growth of the creative economy sector in rural areas, where this operation is the key market for the introduction and sale of creative products from rural communities, ranging from tourism, culinary, craft and other cultural sectors. He (2018) in his study also states that the involvement of the cultural industry has a very significant effect on long-term economic growth efforts in an area.

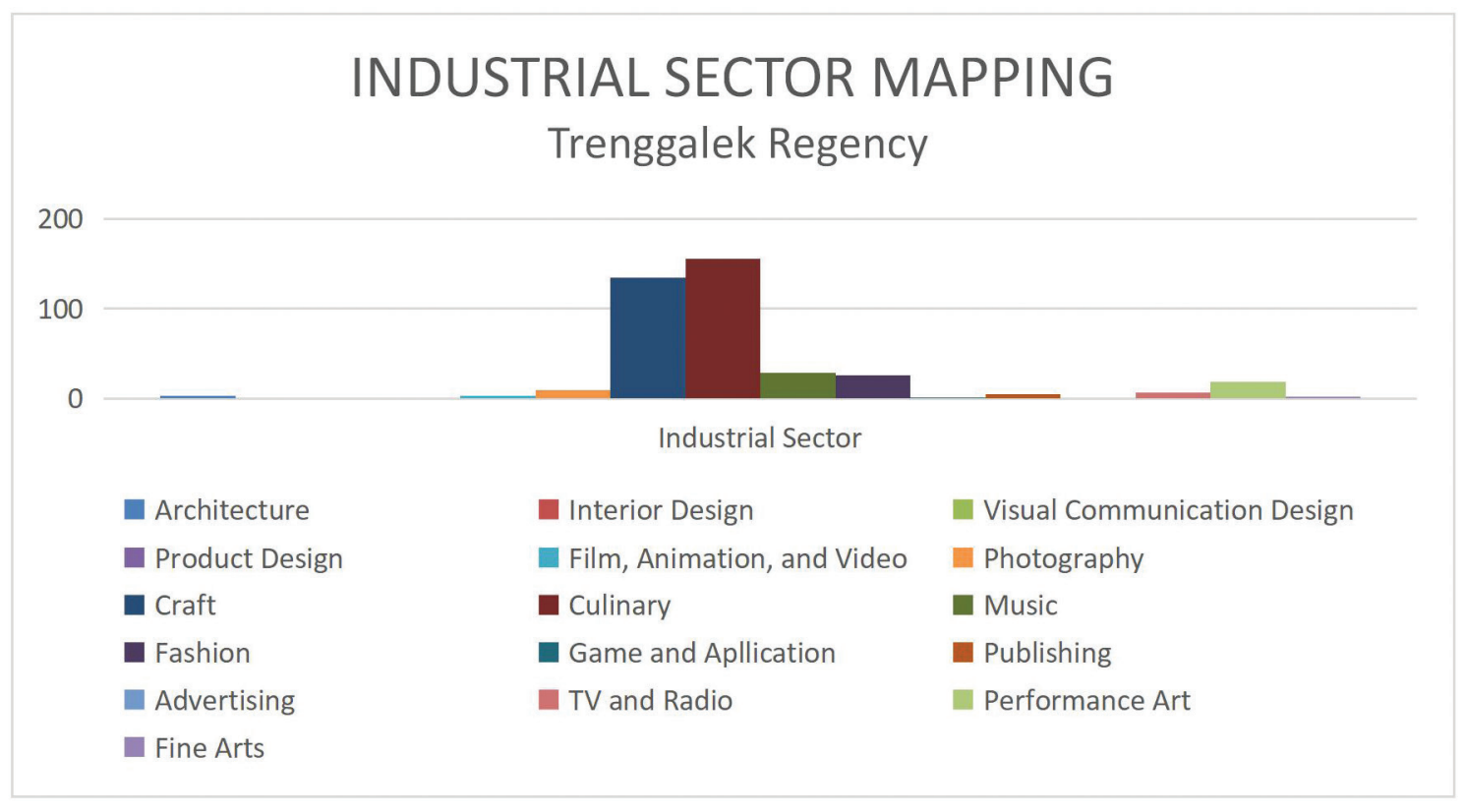

Figure 1: Industrial Sector Graph in Trenggalek 
Furthermore, an action plan related to the TV and radio industry sector includes Talkshow Radio and Writerpreneur. Action plans related to the publishing industry sector include the Book Fair and Children's Book Workshop. Action plans related to the architecture and film industry sector involve the Regional Film Creation Competition and the Nusantara Theater Performance. Action plans related to the art industry sector include Wayang Ndongeng, Jaranan Turangga Yaksa Festival, Woodever Festival, and Indonesian Wayang Festival. As for the action plan related to the animation and video industry sector and the application and game industry sector and other sectors, it can be done through cultural shows, Trenggalek People's Party, GIFT (Trenggalek Creative Innovation Title), Ethnic Carnival Parade, and Creativepreneur Workshop as action plans common to all subsectors. Fleischmann et al. (2017) views that the implementation of incubators such as meeting forums, workshops, etc. is to gather creative industry players to discuss issues and important progress being made, as an effort to encourage the creative economy sub-sector which is still small in scale in area. In an effort to develop human resources for the creative economy in rural areas, Rustantono et al. (2020) emphasized that one type of literacy that must be created is economic literacy in relation to understanding the issue of global warming in order to create a competitive advantage in an environment friendly rural economy. Another important support is the availability of fast quality internet to support creative economy activities in rural environments (Doyle, 2016; Townsend et al., 2017).

\subsection{Creative Economy Strategy Efforts in Trenggalek Regency}

Creative economic actors ought to introduce innovative strategies to develop their businesses (Hauge, 2012; Schmidt et al., 2018). More generally, the central government of a country needs to establish policies that support the creative economy sector (Kong, 2011; Metze, 2009) and, to a lesser degree, regional sectors (cities/districts) should adopt policies (Fleischmann et al., 2017) by adjusting the conditions of the creative economy sectors in their respective regions. Schmidt et al. (2018) in their study offer a range of alternatives for creative industry players to improve their creative business strategies, such as partnering with creative partners, establishing creative communities, and urging the government to establish an unbiased legal framework.

Industrial development efficiency and productivity to increase competitive advantage needs to be enforced with a policy strategy to structure supporting industries, including structuring raw materials regulations, cultivation, relocation, and innovation study of alternative raw materials, creating incentives for the export and import of innovative industrial products / services. Increasing creativity with local content is essential to create a competitive edge through a plan to revitalize import regulations for the creative industry that encourage technology and connectivity tariffs. Strengthening a favorable business environment to promote investment and technology infrastructure by reviewing export policies for biological commodities, which are the key raw materials for the creative industry, making trade regulations for biological commodities for creative industries that support commodity farmers and entrepreneurs in the creative field. The development of awards for intellectual property rights holders/owners and recognition of their economic benefits is also a strategy pursued by reinforcing the basis for business interactions between companies and related creative individuals in the form of standard business contracts respecting IPR (Intellectual Property Rights). To increase an appreciation of local cultural arts, it is carried out by awarding regional culture quality products with a strategy to advocate the use of domestic creative products, in particular East Java is publicly recognized as a regional culture center, therefore strategy should be devised and implemented for the visibility and international recognition of cultural content products / services from East Java. The creative economy's realization through the creative industry needs strategic initiatives that can benefit.

\subsubsection{City Branding}

City branding needs to be done as an attempt to shape a distinctive brand for a product or area, particularly for those working toward certain goals. Branding is not just words but a representation of conveyed symbolic values and contributes to the promotion of preferences or lifestyles relating to the branded product or region (Gómez et al., 2018). Anholt (2008), in his study exploring the use of branding for a place/ area, defines city branding as a mixture of the location's people, intention and reputation and does not always equate it with income. City branding is also used by government actors as a bridge into their ability to provide a region that many individuals know.

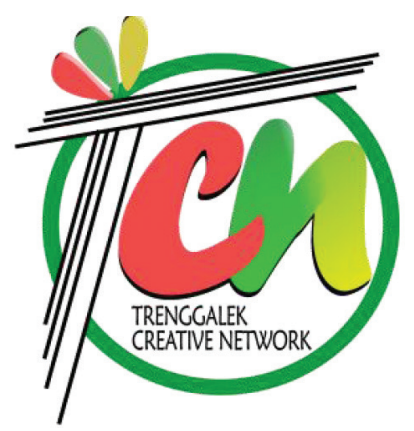

Figure 2: TCN Icon as City Branding for the Creative Economy of Trenggalek Regency 
The researchers chose Trenggalek Creative Network (TCN) as the chosen city brand in an attempt to grow the creative economy sector in Trenggalek Regency and this is a symbol developed in the Trenggalek region to create an innovative and independent creative industry growth ecosystem. The city branding logo for Trenggalek Regency is presented in Figure 2. The logo can be described as follows, the four pillars shown in the upper letter " $\mathrm{T}$ " are inspired by the four components in Trenggalek Regency 's vision, which include the realization of an advanced, equal, prosperous value of Trenggalek Regency and having a characteristics based on belief and spirituality which are represented by the green circle in the TCN logo. At the bottom the four pillars of the letter " $T$ " identify the four Trenggalek Regency missions. This indicates that the 2019-2023 Development of the Creative Economy outlined within the BEKRAF Strategic Plan (2007) is implemented in the form of an action plan through a program which is in line with the Trenggalek Regency vision and purpose. The symbol of three flower petals at the top of the letter " $T$ " reflects the three objectives of developing the TCN management bureaucratic apparatus which is in line with Trenggalek's first mission of improving the performance of clean, competent and skilled bureaucracy for successful and efficient growth.

\subsubsection{Creative Industry Center}

The formation of a group that includes creative economic actors must be created as an attempt to stimulate the sustainability of creative ideas from actors in the creative economy sector (Fleischmann et al., 2017). By initiating dialogues in workshop forums or the like, this can be achieved. In our opinion, the Creative Industry Center is characterized as a place comprising various types of activities to support the growth of the smaller scale creative economy sector, which include the creative industry. The Creative Industry Center's principal functions include four operations, including production, education, exhibition, and marketing. Thus all the facilities in it must be able to support certain activities, namely regional business incubators, education (training and literacy centers for the growth of creative economy), exhibitions or exhibits, and marketing. According to a study conducted by Potluri and Potluri (2016), the government and stakeholders must also make efforts to increase access to ICT, because its presence in the telecommunications and education sectors has proven capable of building the capacity of human resources in rural areas.

\subsubsection{Renewable Resources}

The creation of creative industries using natural resources is aimed at using sustainable natural resources in a way that ensures their availability for future generations. This is also proven in an analytical study conducted by Dahliah et al. (2020) on the subject of Bantaeng Regency, Indonesia, where it was found that it is important to prioritize rural economic development that involves the potential of native regional resources. Some of the strategies implemented to improve local resource use and growth include: 1) the growth of creative capital, specifically talented individuals as the basis for creative economic development; and 2) the protection of cultural resources as raw materials for the emergence of the creative economy sector in the rural areas. Trenggalek Creative Network (TCN) can be accomplished by fulfilling eight requirements, particularly regarding: 1) local creative community; 2) creative environment that could really foster creativity and innovation (for instance creative center, technology park, incubator); 3) a public space that becomes an activity and interaction between parties of the creative economy (government, actors of business/ industry, intellectuals, and creative community/forum); 4) local potential as a dominant aspect and district identity; 5) ecosystems that incorporate part or all of the development, production and distribution / market processes; 6) district infrastructure which might inspire creativity; 7) District Government development programs related to creativity and innovation; 8) a forum for collaboration between the government, the creative community, the business parties and academia.

\subsection{Discussion}

The goal of this article is to discuss the development of the creative economy sector in rural communities in Trenggalek Regency, East Java, Indonesia. Implementation is carried out by mapping the sub-sector of the creative economy, which has the greatest potential to be established, taking into account the potential of human capital, culture and current trends. Previously, the growth of the creative economy field concentrated only on urban populations that were considered to be closely connected to technology (Bell \& Jayne, 2010; Tao et al., 2019). However, times and increasingly prevalent regional growth promote the development of the creative economy sector in rural areas, while preserving the cultural richness and uniqueness of rural life (Fahmi et al., 2016). After mapping the creative economy sub-sector in Trenggalek Regency, it was found that four of the sixteen sub-sectors had the potential to grow, such as the culinary sub-sector with a total of 155 industry stakeholders dominated by the local culinary component of Trenggalek Regency, a sub-sector of the craft industry consists of 134 industry representatives, a sub-sector of music industry consists of 29 industry players, and a fashion industry sub-sector consists of 26 industry representative dominated by hand-drawn batik fashion as its potential product. 
The path and policies for the growth of the creative economy in Trenggalek Regency need to be adopted, first of all, by urban branding efforts in the Trenggalek Creative Network (TCN). This is done to establish the branding of Trenggalek Regency as a district that accommodates its citizens in the growth of the creative economy sector in rural areas. Branding is intended not only as a picture but also as an incentive to seriously create Trenggalek Regency, which supports the growth of the creative economy sector at the stage of implementation. Second, through the Creative Industry Hub, which provides creative economy incubators for the citizens of Trenggalek Regency, who serve as creative economy actors, and which includes efforts to help communities that have sustainable creative ideas to work in the creative economy field in the village life landscape. Third, through growing the number of quality innovative human capital on a continuous basis, through a strategy to create access to information and knowledge sharing within the society, both physically and non-physically, such as information technology on a regional, national and international scale. Government support at the legal framework level in the form of legislation that supports the development of the creative economy sector seems to be very much required.

The study also disproves the argument that the creative economy sector can only be established in urban communities along with its propensity to be close to technologies (Roberts \& Townsend, 2016). This is because the growth of the creative economy sector currently often involves companies with a cultural history that belongs to a specific region (Fahmi et al., 2016), which means that the creative economy sector is not always about sophisticated technology. Although the simple village life landscape is very dense in Trenggalek Regency, technological advances have begun to penetrate and inspire people to take part in the creative economy domain, such as in the area of games and animation, photography and music. While the numbers are indeed limited, at least the elements of the creative economy that appear to be urbanized can be created while preserving a local cultural heritage and a rural environment that appears to be pleasant and rich in natural resources.

\section{Conclusions}

Through three strategic paths and policies for the growth of the creative economy, it is intended that the initiative will be compatible and interconnected with other projects in the respective agencies in the future. Budget alignment support is required to achieve a creative economy roadmap that can create regional capacity based on local wisdom. In addition, there is also a need to improve human capital, both the apparatus, the innovative economic actors and the culture, in order to promote the revival of local practices, which would later have an impact on regional activities. In addition, it is important to carry out research that analyzes the sustainability of the creative economy sector, including those involved in rural areas with quantitative analysis estimates, in order to identify the growth of the creative economy sector in rural areas with more accurate data. In addition, debates on the creative economy sector in rural areas in other areas also need to be examined, including mapping, thus the advantages of the creative economy can be progressively felt by the rural communities.

\section{References}

Anderson, A. R., Wallace, C., \& Townsend, L. (2016). Great Expectations or Small Country Living? Enabling Small Rural Creative Businesses with ICT: Great expectations or a small country living? Sociologia Ruralis, 56(3), 450-468. https://doi. org/10.1111/soru.12104

Andres, L., \& Round, J. (2015). The creative economy in a context of transition: A review of the mechanisms of micro-resilience. Cities, 45, 1-6. https://doi.org/10.1016/j.cities.2015.02.003

Anholt, S. (2008). Place branding: Is it marketing, or isn't it? Place Branding and Public Diplomacy, 4(1), 1-6. https://doi. org/10.1057/palgrave.pb.6000088

Atana, T., \& Purwohandoyo, J. (2016). Support of The Prigi Beach Tourism Area In Watulimo District, Trenggalek District. 15(1), 13. https://doi.org/10.15294/jg.v15i1.11249

Baeker, G., \& Taylor, D. (2008). Economic restructuring through culture in small towns and rural areas: Building creative rural economies: A case study of Prince Edward County, Ontario. In: The International Forum on the Creative Economy, Gatineau, Quebec.

Bekraf. (2019). Creative Economy Outlook 2019 (OPUS Indonesia). Creative Economy Agency, Republic of Indonesia.

Bell, D., \& Jayne, M. (2010). The creative countryside: Policy and practice in the UK rural cultural economy. Journal of Rural Studies, 26(3), 209-218. https://doi.org/10.1016/j. jrurstud.2010.01.001

Coles, A. (2016). Creative class politics: Unions and the creative economy. International Journal of Cultural Policy, 22(3), 456472. https://doi.org/10.1080/10286632.2014.994612

Dahliah, D., Kurniawan, A., \& Putra, A. H. P. K. (2020). Analysis and Strategy of Economic Development Policy for SMEs in Indonesia. Journal of Asian Finance, Economics and Business, 7(5), 103-110. https://doi.org/10.13106/jafeb.2020.vol7. no5.103

de Figueiredo, J. L., Santos Vieira de Jesus, D., Tavares Robaina, D., \& Lohmann Couri, C. (2019). The development potential index of creative economy for Brazilian federal state capitals. Creative Industries Journal, 12(2), 185-203. https://doi.org/10 $.1080 / 17510694.2019 .1610344$

Fahmi, F. Z., Koster, S., \& van Dijk, J. (2016). The location of creative industries in a developing country: The case of 
Indonesia. Cities, 59, 66-79. https://doi.org/10.1016/j. cities.2016.06.005

Faradiba, F., \& Zet, L. (2020). The Impact of Climate Factors, Disaster, and Social Community in Rural Development. Journal of Asian Finance, Economics and Business, 7(9), 707717. https://doi.org/10.13106/jafeb.2020.vol7.no9.707

Fathurahman, H., \& Huseini, M. (2018). Mapping of Regional Economic Potential Based on Creative Economy to Support Creation of Regional Competitiveness. KnE Social Sciences, 3(10), 310. https://doi.org/10.18502/kss.v3i10.2918

Fazlagić, J., \& Skikiewicz, R. (2019). Measuring sustainable development: The creative economy perspective. International Journal of Sustainable Development \& World Ecology, 26(7), 635-645. https://doi.org/10.1080/13504509.2019.1651418

Fleischmann, K., Welters, R., \& Daniel, R. (2017). Creative Industries and Regional Economic Development: Can A Creative Industries Hub Spark New Ways to Grow A Regional Economy? 26.

Florida, R., \& Adler, P. (2019). The Creative Class and the Creative Economy. In Reference Module in Neuroscience and Biobehavioral Psychology (p. B9780128093245237 000). Elsevier. https://doi.org/10.1016/B978-0-12-8093245.23766-8

Gómez, M., Fernández, A. C., Molina, A., \& Aranda, E. (2018). City branding in European capitals: An analysis from the visitor perspective. Journal of Destination Marketing \& Management, 7, 190-201. https://doi.org/10.1016/j.jdmm.2016.11.001

Guilherme, L. L. (2017). Creative economy: Thematic perspectives addressed and research methodologies adopted. Brazilian Journal of Science and Technology, 4(1), 2. https://doi. org/10.1186/s40552-017-0040-0

Hauge, A. (2012). Creative industry: Lacklustre business: Swedish fashion firms' combination of business and aesthetics as a competitive strategy. Creative Industries Journal, 5(1-2), 105-118. https://doi.org/10.1386/cij.5.1-2.105_1

He, Y. (2018). A Study on the Dynamic Relationship between Cultural Industry and Economic Growth. Journal of Asian Finance, Economics and Business, 5(4), 85-94. https://doi. org/10.13106/jafeb.2018.vol5.no4.85

Howkins, J. (2001). The Creative Economy: How People Make Money from Ideas. Penguin Group (USA) Incorporated.

Hsiao, S., Wang, P., Chiu, C., Chung, G., Peng, K., \& Shih, M. (2010). A study of Linkage Analysis on The Cultural and Creative Industries. International Journal of Information Processing and Management, 1(2), 133-139. https://doi. org/10.4156/ijipm.vol1.issue2.16

Kim, T. (2017). Creative Economy of the Developmental State: A Case Study of South Korea's Creative Economy Initiatives. The Journal of Arts Management, Law, and Society, 47(5), 322-332. https://doi.org/10.1080/10632921.2017.1377660

Kong, L. (2011). From precarious labor to precarious economy? Planning for precarity in Singapore's creative economy. City,
Culture and Society, 2(2), 55-64. https://doi.org/10.1016/j. ccs.2011.05.002

Metze, T. A. P. (2009). Discursive power in deliberations: A case of redevelopment for the creative economy in the Netherlands. Policy and Society, 28(3), 241-251. https://doi.org/10.1016/j. polsoc.2009.08.006

Moreton, S. (2018). Contributing to the creative economy imaginary: Universities and the creative sector. Cultural Trends, 27(5), 327-338. https://doi.org/10.1080/09548963.20 18.1534575

Munro, E. (2017). Building soft skills in the creative economy: Creative intermediaries, business support and the 'soft skills gap". Poetics, 64, 14-25. https://doi.org/10.1016/j. poetic.2017.07.002

Oakley, K., \& Ward, J. (2018). Creative Economy, Critical Perspectives. Cultural Trends, 27(5), 311-312. https://doi.org /10.1080/09548963.2018.1534573

Perpres No 72 Year. (2015). Presidential Regulation of the Republic of Indonesia Number 72 of 2015 concerning Amendments to Presidential Regulation Number 6 of 2015 concerning the Creative Economy Agency. https://peraturan. go.id, 139, 1-5.

Potluri, R. M., \& Potluri, L. S. (2016). A Structural Compendium on Perceptual Displays of Rural India towards the Role and Impact of ICT. Journal of Asian Finance, Economics and Business, 3(4), 81-90. https://doi.org/10.13106/jafeb.2016.vol3.no4.81

Reis, A. C. F. (2008). Creative economy as a development strategy. Itaú Cultural.

Roberts, E., \& Townsend, L. (2016). The Contribution of the Creative Economy to the Resilience of Rural Communities: Exploring Cultural and Digital Capital: Creative economy and rural community resilience. Sociologia Ruralis, 56(2), 197219. https://doi.org/10.1111/soru.12075

Rustantono, H., Soetjipto, B. E., Wahjoedi, W., \& Sunaryanto, S. (2020). Socio-Economic Factors and Rural Competitive Advantage: The Moderating Role of Economic Literacy. Journal of Asian Finance, Economics and Business, 7(8), 151159. https://doi.org/10.13106/jafeb.2020.vol7.no8.151

Schlesinger, P. (2017). The creative economy: Invention of a global orthodoxy. Innovation: The European Journal of Social Science Research, 30(1), 73-90. https://doi.org/10.1080/13511 610.2016 .1201651

Schmidt, S., Schreiber, D., Bohnenberger, M. C., \& Pinheiro, C. M. P. (2018). Strategic design in small creative industry firms. Creative Industries Journal, 11(3), 306-321. https://doi.org/10. 1080/17510694.2018.1526606

Sopanah, A., Bahri, S., \& Ghozali, M. (2018). Creative Economic Development Strategy in Malang City. KnE Social Sciences, 3(10). https://doi.org/10.18502/kss.v3i10.3386

Strzelecka, E. (2016). The Creative Sector in Rural Areas in the Policy of Balanced Regional Development. Barometr Regionalny. Analizy i Prognozy, 14(4), 15-21. 
Tao, J., Ho, C. Y., Luo, S., \& Sheng, Y. (2019). Agglomeration economies in creative industries. Regional Science and Urban Economics, 77, 141-154. https://doi.org/10.1016/j. regsciurbeco.2019.04.002

Townsend, L., Wallace, C., Fairhurst, G., \& Anderson, A. (2017). Broadband and the creative industries in rural Scotland. Journal of Rural Studies, 54, 451-458. https://doi.org/10.1016/j. jrurstud.2016.09.001

Trenggalek District. (2014). Government of Trenggalek District [Government Website]. Trenggalek Regency Government. https://www.trenggalekkab.go.id/index.php

Tsai, H., Song, H., \& Wong, K. K. F. (2009). Tourism and Hotel Competitiveness Research. Journal of Travel
\& Tourism Marketing, 26(5-6), 522-546. https://doi. org/10.1080/10548400903163079

UNCTAD. (2018). Creative Economy Outlook Trends in international trade in creative industries 2002-2015 Country Profiles 2005-2014 (UNCTAD/DITC/TED/2018/3). United Nations Conference on Trade and Development (UNCTAD). https://unctad.org/en/PublicationsLibrary/ditcted2018d3_en.pdf

White, P. (2010). Creative industries in a rural region: Creative West: The creative sector in the Western Region of Ireland. Creative Industries Journal, 3(1), 79-88. https://doi.org/10.1386/cij.3.1.79_1

Wilson, N. (2010). Social creativity: Re-qualifying the creative economy. International Journal of Cultural Policy, 16(3), 367381. https://doi.org/10.1080/10286630903111621 